\title{
Evaluation of antimicrobial activity of chondrillasterol isolated from Vernonia adoensis (Asteraceae)
}

\author{
Winnie Mozirandi ${ }^{1}$, Dexter Tagwireyi ${ }^{2}$ and Stanley Mukanganyama ${ }^{1 *}$ (D)
}

\begin{abstract}
Background: Bacteria have developed resistance to most of the current antibiotics. There is evidence suggesting that plant-derived compounds have a potential for interacting with biological processes. One of the plants commonly used in African ethnomedicine is Vernonia adoensis from the Asteraceae family. The leaves of the plant have been reported to have antimicrobial activity. Hence, the aim of this study was to isolate the bioactive compounds from the leaf extract and evaluate their antibacterial activity on Staphylococcus aureus, Klebsiella pneumoniae and Pseudomonas aeruginosa. In addition, the effect of the isolated compound on biofilms of $P$. aeruginosa was determined.

Methods: Isolation of phytochemicals from the leaves of $V$. adoensis was done using column chromatography. Preparative TLC was used to further isolate mixed compounds in the fractions. Nuclear magnetic resonance spectroscopy and mass spectrometry was used to identify the isolated pure compounds. The broth microdilution assay was carried out to evaluate the antibacterial activity of the isolated compound on P. aeruginosa, S. aureus and K. pneumoniae. Crystal violet staining technique was used to evaluate the effect of the isolated compound on biofilms of $P$. aeruginosa.

Results: The compound isolated from V. adoensis was identified as chondrillasterol. Chondrillasterol exhibited 25, 38 and $65 \%$ inhibition of growth on S. aureus, K. pneumoniae and P. aeruginosa respectively. At $1.6 \mu \mathrm{g} / \mathrm{mL}$ chondrillasterol completely disrupted mature biofilm of $P$. aeruginosa while at $100 \mu \mathrm{g} / \mathrm{mL}$ the compound completely inhibited formation of biofilms of the bacteria.

Conclusion: Chondrillasterol isolated from V. adoensis has antibacterial properties against S. aureus, K. pneumoniae and $P$. aeruginosa. The compound also has biofilm inhibition and disruption activity against $P$. aeruginosa biofilms. Thus, the active phytochemical could be a useful template for the development of new antimicrobial agents with both antibacterial and antibiofilm activity.
\end{abstract}

Keywords: Vernonia adoensis, Antibacterial, Biofilms, Chondrillasterol

\section{Introduction}

Bacteria have developed resistance to most of the currently used antibiotics [1], thus, making bacterial infections a major cause of mortality in the health care system [2]. There is evidence to suggest that bacterial infections are becoming difficult to treat because the pathogens are capable of developing biofilm which aids in host establishment, population expansion and in disease proliferation [3]. More than $60 \%$ of all the human

\footnotetext{
* Correspondence: smukanganyama@medic.uz.ac.zw

${ }^{1}$ Department of Biochemistry, University of Zimbabwe, P.O. Box MP 167, Mt. Pleasant, Harare, Zimbabwe

Full list of author information is available at the end of the article
}

bacterial infections have been attributed to the persistence of biofilm formation by the respective bacteria [4]. When bacteria form biofilms, the biofilm structure facilitates the survival of disease-causing pathogens even in hostile environmental conditions. It has been shown that the nature of biofilm structure and physiological attributes of biofilm forming organisms confer an inherent resistance to hostile conditions including antimicrobial agents such as antibiotics [5]. Hence, there is need to develop new antibacterial agents which can inhibit formation or destroy the mature biofilms and thus, increasing susceptibility of microbes to antibiotics.

(c) The Author(s). 2019 Open Access This article is distributed under the terms of the Creative Commons Attribution 4.0 International License (http://creativecommons.org/licenses/by/4.0/), which permits unrestricted use, distribution, and reproduction in any medium, provided you give appropriate credit to the original author(s) and the source, provide a link to the Creative Commons license, and indicate if changes were made. The Creative Commons Public Domain Dedication waiver (http://creativecommons.org/publicdomain/zero/1.0/) applies to the data made available in this article, unless otherwise stated. 
There is an increasing interest in the use of medicinal plant-derived compounds as alternative antibacterial agents [6]. Plants have formed the basis of traditional medicinal systems that have been in existence for thousands of years, and continue to provide humanity with new remedies [7]. Some of the drugs which are widely used in clinical practice have been obtained from plants [8]. Vernonia adoensis is a plant which is commonly used in African ethnomedicine [9]. It is a herbaceous plant from the Vernonia genus belonging to the family Asteraceae which is the largest genus with close to 1000 species [10]. In East Africa the decoction of the roots is mixed with other trees for the treatment of heart and kidney problems [11]. In the Rift valley and Western part of Kenya, $V$. adoensis is used traditionally to treat symptoms of sexually transmitted diseases such as gonorrhea [11]. The leaves of the plant are also used in the treatment of the symptoms of malaria [12]. In Tanzania this plant has been traditionally used in African ethnomedicine for the treatment of fever and upper respiratory tract infections [9]. $V$. adoensis is native and commonly distributed throughout Zimbabwe where it is known in vernacular Shona language as Musikavakadzi [13].

Several studies have been carried out to evaluate the antimicrobial potential of $V$. adoensis with the ultimate goal of justifying the traditional use of the plant species or discovering drugs $[14,15]$. The plant extracts have shown antibacterial activity against Staphylococcus aureus, Pseudomonas aeruginosa, Bacillus cereus and Bacillus subtilis in-vitro [16]. The plant leaves have been reported to have very high anti-plasmodial activity against Plasmodium falciparum [17]. Chimponda and Mukanganyama [18], reported that the leaves of $V$. adoensis had inhibitory activity against Mycobacterium aurum and Corynebacterium glutamicum. There are studies which have been done to isolate phytochemicals from some Vernonia species and the compounds isolated were shown to have biological activities [19-21]. $V$. adoensis has been shown to possess some important pharmacological phytochemicals [21] but there is limited information on the biological activity of the specific compounds isolated from the plant. Most of the biological activity tests from the various studies were conducted using crude extracts obtained from different parts of the plant. Hence, the need to isolate phytochemicals from $V$. adoensis as they may yield lead compounds that have significant antimicrobial potential against selected strains of bacteria. Studies have shown that bacteria such as P. aeruginosa, S. aureus and K. pneumoniae are among the major causes of nosocomial infections that have produced a poor prognosis in the hospital [22]. From the advent of antimicrobial application in treatment of bacterial diseases, pathogenic bacteria have responded by developing varied forms of resistance [23]. Klebsiella pneumoniae has become resistant to carbapenem antibiotics which are often the last line of defense against Gram-negative infections [24]. Staphylococcus aureus strains are now resistant to penicillin [25]. In most Asian countries, $70-80 \%$ of the same strain have become methicillin-resistant [25]. Pseudomonas aeruginosa infections are now responsible for most nosocomial infections in hospitals and healthcare centers because there are no effective antimicrobial agents against it [26]. Also infection by $P$. aeruginosa through biofilm in lungs of cystic fibrosis $(\mathrm{CF})$ patients is causing high morbidity and functional failure of this organ [27].

There is need for new antibacterial agents as bacteria have developed resistance to most of the currently used antibiotics [1]. In addition, current antibiotics have considerable limitations in terms of antimicrobial spectrum and side effects [28]. The indiscriminate use and misuse of antibiotics has led to increasing clinical resistance of previously sensitive microorganisms and to the occurrence of uncommon infections. Plant-based natural products have been found to be a rich source of antimicrobial agents [29]. Traditional medicinal plants have received significant attention as a source of new chemical entities because their phytochemicals may lead to new leads in drug discovery [30]. The aim of this study was to isolate the phytochemicals found in $V$. adoensis and evaluate their antimicrobial activity since previously the crude extracts were shown to have high antibacterial activities [31].

\section{Materials and methods}

Permission to use the plant

The collection and use of the plant for the study was approved by the ethical committee of the Faculty of Science Higher Degrees, University of Zimbabwe, paper HD/166 of 2016.

\section{Plant material collection}

Vernonia adoensis was collected in Centenary, (Geographic coordinates, Latitude: $16^{\circ} 43^{\prime} 22^{\prime \prime}$ S, Longitude: $31^{\circ} 06^{\prime} 52^{\prime \prime}$ E, elevation above sea level: 1156) Mashonaland Central Province of Zimbabwe. Plant collection was done during the month of March 2018. Authentication and classification of the plant was done by a taxonomist from the National Herbarium and Botanic Garden (Harare, Zimbabwe). Herbarium samples C1 E7, were kept at the National Herbarium and Botanic Garden (Harare, Zimbabwe) and the Department of Biochemistry, University of Zimbabwe.

\section{Preparation of acetone extract}

A previous study of evaluation of antibacterial activity of extracts from $V$. adoensis had shown the acetone extract to possess the most potent antibacterial activity [31] hence, the extract used in this study was prepared using acetone. $V$. adoensis leaves were washed under running 
tap water and dried in the oven at $40^{\circ} \mathrm{C}$. The dried leaves were pounded in a clean mortar and further ground in a two speed blender (Cole Parmer Instrument CO.,Vernon Hills, USA) to obtain a fine powder $(4 \mathrm{~kg})$ to which acetone (Sigma-Aldrich, Taufkirchen, Germany) was added to extract the photochemical by maceration [32]. The mixture was left for $72 \mathrm{~h}$ shaking on a magnetic stirrer for effective extraction of the plant components. The extract obtained was then filtered using WHATMAN's no 1 filter paper (Sigma-Aldrich, Taufkirchen, Germany) into sterile beakers and the filtrate concentrated to dryness by evaporation at room temperature in a fume hood with an air stream. The dry extract was stored at $4{ }^{\circ} \mathrm{C}$ for further use.

\section{Bacteria and culture conditions}

Staphylococcus aureus (ATCC 9144) and Pseudomonas aeruginosa (ATCC 27853) were obtained from the Division of Microbiology, Department of Biological Sciences at the University of Botswana. A clinical strain of Klebsiella pneumoniae were obtained from Parirenyatwa Hospital (Department of Medical Microbiology College of Health Sciences, Harare, Zimbabwe). Bacteria were inoculated into tryptic soy broth media and incubated overnight at $37^{\circ} \mathrm{C}$ with shaking at $2 \mathrm{~g}$-force in a LabCompanion incubator (SI300 Incubated shaker, Jeio Tech, Korea). The bacterial cultures were centrifuged at $2068 \mathrm{~g}$-force for $4 \mathrm{~min}$ in a Hettich Rotofix 32 centrifuge (Tuttlingen, Germany) and the supernatant discarded. The pellets were washed twice in phosphate-buffered saline and suspended in fresh media. The cells were standardised according to $0.5 \mathrm{McF}$ arland standards to create inoculum densities of $2 \times 10^{6} \mathrm{cfu} / \mathrm{mL}$ for use in the antibacterial activity determination assay, and bacterial broth cultures of $5 \times 10^{8} \mathrm{cfu} / \mathrm{mL}$ for biofilm assays.

\section{Isolation of compounds}

Isolation of compounds from the crude extract was done by column chromatography. The dried acetone extract $(156 \mathrm{~g})$ was dissolved in minimum quantity of distilled methanol and warmed in a water bath at $97^{\circ} \mathrm{C}$ until completely dissolved. The solubilised extract was adsorbed on silica gel (60) and dried at room temperature. The column $(6 \times 90 \mathrm{~cm})$ was prepared using silica gel $(60-120$ mesh $)$ suspended in $n$-hexane. The extract adsorbed to silica was ground to powder and then poured onto the stationary phase. The column was run by gradient elution technique using hexane, ethyl acetate and methanol. A total of 450 fractions each with $250 \mathrm{~mL}$ were collected and characterised by TLC on silica gel plates. The spots developed were visualised at 254 and $365 \mathrm{~nm}$ using A425/G Allen Ultraviolet light (P. W. ALLEN \& Co., London, UK). The TLC plate was sprayed with $5 \%$ sulphuric acid and incubated for $10 \mathrm{~min}$ at $120^{\circ} \mathrm{C}$. The fractions which showed the same TLC development profiles were pooled and allowed to dry at room temperature till the solvent evaporated. The fractions were placed on filter paper over a conical flask and washed to remove impurities. Washing of fractions was done using a solvent of higher polarity relative to the eluent. The washed compounds were left to dry at room temperature and thin layer chromatography was carried out to determine the purity of the dried compounds. All the fractions except for fraction 10 were in minute quantities such that no further analysis could be done with them. Fraction 10 was further purified using preparative TLC using $20 \times 20 \mathrm{~cm}$ TLC silica gel 60 glass plates (Sigma-Aldrich, St. Louis Missouri, USA). Two bands were visible under UV at $254 \mathrm{~nm}$ and $366 \mathrm{~nm}$ and these were scrapped into separate beakers and labelled F10b1 and F10b2. To extract the compounds from the silica gel, they were placed on a filter paper (Whatman \# 1 , Sigma-Aldrich, Darmstad, Germany) on a funnel and chloroform was used to dissolve them. The purity of the compounds in the filtrate was checked by TLC analysis. The compounds eluted and collected as filtrates F10b1 and F10b2 were air dried and stored in vials (Chromacol clear $2 \mathrm{~mL} \mathrm{S/T} \mathrm{vials,} \mathrm{Sigma-Aldrich,} \mathrm{St.} \mathrm{Louis} \mathrm{Missouri,}$ USA) for further use.

\section{Spectral identification of compounds}

NMR spectroscopic analysis were carried out at the Institute of Chemistry Potsdam, Germany. Samples F10b1 and F10b2 were dissolved in $\mathrm{CD}_{2} \mathrm{Cl}_{2}$ then $1 \mathrm{D}$ and $2 \mathrm{D}$ NMR spectra were recorded on a BRUKER AVANCE 500 spectrometer (Billerica, Massachusetts, USA). Residual solvent peaks of $\mathrm{CD}_{2} \mathrm{Cl}_{2}$ were used as a reference. Agilent HPLC 1260 System coupled to an Agilent QTOF 6530 Mass spectrometer was used to confirm the formula of the compound.

\section{Antibacterial activity of chondrillasterol}

Chondrillasterol (Fig. 3) was identified as one of the compounds that were isolated from $V$. adoensis. The antibacterial activities of this compound against $P$. aeruginosa, S. aureus and $K$. pneumoniae were determined in-vitro using the broth microdilution method following guidelines from [33]. Two-fold serial dilutions of the pure compound from (12.5 to $100 \mu \mathrm{g} / \mathrm{mL})$ were prepared and a volume of $100 \mu \mathrm{L}$ was separately added to the wells of a 96-well microplate. To each of the wells $100 \mu \mathrm{L}$ of bacterial cells were added to give a final concentration of $1 \times 10^{6} \mathrm{cfu} / \mathrm{mL}$. Ten two-fold serial dilutions of ciprofloxacin $(0-100 \mu \mathrm{g} / \mathrm{mL})$ as well as levofloxacin were also prepared and $100 \mu \mathrm{L}$ added to wells of the plate containing an equal volume of cells. Ciprofloxacin was added to $P$. aeruginosa and $S$. aureus cells while levofloxacin was added to wells with $K$. pneumoniae. The wells with tryptic soy broth served as the sterility control and wells with cells only served as the 
negative control. Pre-incubation absorbance readings of the plate were measured at $590 \mathrm{~nm}$ using the microplate reader (Tecan Genios-Pro microplate reader, Grödig, Austria) and the plate was incubated overnight without shaking at $37^{\circ} \mathrm{C}$ in a LAB Doctor Mini Incubator (MID SCI, USA). The cell density was also determined after $20 \mathrm{~h}$ of incubation. Viability of cells after exposure to the extract was further evaluated by addition of $20 \mu \mathrm{L}$ aliquots of $2 \mathrm{mg} / \mathrm{mL}$ 3-(4,5-dimethylthiazol-2-yl)-2,5- diphenyltetrazolium bromide (MTT) to each of the wells of the plate and incubating the plate at $37^{\circ} \mathrm{C}$ for $2 \mathrm{~h}$. Viable bacteria reduce the yellow MTT dye to a purple formazan [34].

\section{Effect of chondrillasterol on nucleic acid leakage}

Evaluation of the ability of chondrillasterol to disrupt $P$. aeruginosa cells and cause leakage of nucleic acids was done according to the method of El-Nakeeb [35] with some modifications. P. aeruginosa (ATCC 27853) was grown overnight. The overnight culture was centrifuged at $2068 \mathrm{~g}$ for $4 \mathrm{~min}$ in a Hettich Rotofix 32 centrifuge (Tuttlingen, Germany) and the supernatant discarded. The pellet was suspended in $0.9 \%$ sterile saline until $\left(\mathrm{OD}_{600}=\right.$ 1.5). The suspensions were exposed to $100 \mu \mathrm{g} / \mathrm{mL}$ and $50 \mu \mathrm{g} / \mathrm{mL}$ of chondrillasterol and incubated at $37^{\circ} \mathrm{C}$ with shaking (2 g-force) for $10 \mathrm{~min}$ in a Lab-Companion incubator (SI300 Incubated shaker, Jeiotech, Korea). The controls used were cells exposed to $0.1 \%$ SDS for the positive control and untreated cells served as the negative control. From each sample, $1 \mathrm{~mL}$ aliquots were centrifuged at $20427 \mathrm{~g}$-force for $1 \mathrm{~min}$ (Hettich Rotofix 32 centrifuge, Tuttlingen, Germany). The pellet was washed with $0.9 \%$ saline solution and suspended in $3 \mathrm{~mL}$ of saline. A volume of $3 \mu \mathrm{L}$ propidium iodide were added to each sample and the solution was mixed. The samples were kept in the dark for 10 min after which fluorescence was measured at excitation and emission wavelengths of $544 \mathrm{~nm}$ and 612 $\mathrm{nm}$ respectively using an fmax microplate spectrofluorometer (Molecular Devices, Sunnyvale, USA).

\section{Effect of chondrillasterol on formation of biofilm by $P$. aeruginosa}

Evaluation of the ability of the isolated compound which had been identified as chondrillasterol to inhibit formation of $P$. aeruginosa biofilms was carried out using microtiter plate method according to Stepanovic [36] with slight modifications. An overnight culture of $P$. aeruginosa cells in tryptic soy broth supplemented with $1 \%$ glucose was centrifuged at $2068 \mathrm{~g}$-force for $4 \mathrm{~min}$. The inoculum was standardised according to $0.5 \mathrm{McF}$ arland standards to a working suspension corresponding to $5 \times$ $10^{8} \mathrm{cfu} / \mathrm{mL}$. Double serial dilutions of chondrillasterol were performed to cover the range from 0.4 to $100 \mu \mathrm{g} /$ $\mathrm{mL}$ as a final concentration in the wells. To detect the effect of chondrillasterol on biofilm formation, $100 \mu \mathrm{L}$ of appropriate concentrations of the compound were added to six individual wells of a sterile 96-well polystyrene microplate (Greiner 96 well plates, Sigma-Aldrich, Germany) prior to inoculation. An equal volume of the numerically standardised $P$. aeruginosa bacterial suspension were added. The assay was carried out according to the plate lay out shown in Fig. 1. As a negative control to determine background optical density (OD) the first two rows of the plate contained $100 \mu \mathrm{L}$ uninoculated medium added to an equal volume of the compound. In column 11 of the plate, $200 \mu \mathrm{L}$ of bacterial cells only were dispensed and served as the positive control.

Aliquots of media (TSB $+1 \%$ glucose) were dispensed into each of eight wells of column 12 of microtiter plate to serve as a negative control. The plate was incubated in a non-shaking incubator at $37^{\circ} \mathrm{C}$ for $72 \mathrm{~h}$ (Labcon orbital incubator, Labotec Co., Cape Town, South Africa). After incubation medium was decanted into a discard container and wells of the plate were washed twice with $0.9 \%$ sterile saline to remove planktonic bacteria. The contents of wells were emptied by inversion and plate dried upside-down for $15 \mathrm{~min}$ on absorbent paper in a biosafety cabinet (BioFlow-11, Labotec Co., Cape Town, South Africa). The plate was placed in an oven at $60^{\circ} \mathrm{C}$ for an hour to fix the formed biofilm after which $0.1 \%$ crystal violet stain was added to each well and the plate incubated at room temperature for $20 \mathrm{~min}$. Excess stain was rinsed off by decantation and the plate was washed three times with distilled water and left to air dry. After the plate had completely dried, the wells of the plate were filled by $200 \mu \mathrm{L}$ of $95 \%$ ethanol to release the dye from the cells. The density of stained adherent bacteria was determined at $590 \mathrm{~nm}$ using $\mathrm{EL} \times 800$ Tecan Genios-Pro microplate reader (Grödig, Austria). The percentage inhibition of biofilm formation was calculated using the formula in Eq. 1:

$$
\% \text { Biofilm inhibition }=[(\mathbf{A B}-\mathbf{E F}) / \mathbf{G}] \times \mathbf{1 0 0} .
$$

where $A B$ is the optical density of the stained attached bacteria, EF is the optical density of the stained control cultures without microorganisms, and G is the optical density of the bacteria in suspended culture.

Effect of chondrillasterol on mature biofilm of $P$. aeruginosa The effect of chondrillasterol on mature biofilms was determined on 96-well microplates [36]. An overnight culture of $P$. aeruginosa cells was numerically standardised as above and $100 \mu \mathrm{L}$ volume added to each of 6 wells of a polystyrene microplate (Greiner 96 well plates, SigmaAldrich, Germany). As a negative control to determine background optical density (OD) the first two rows of the plate contained $100 \mu \mathrm{L}$ uninoculated medium added to an equal volume of the compound. In column 11 of 


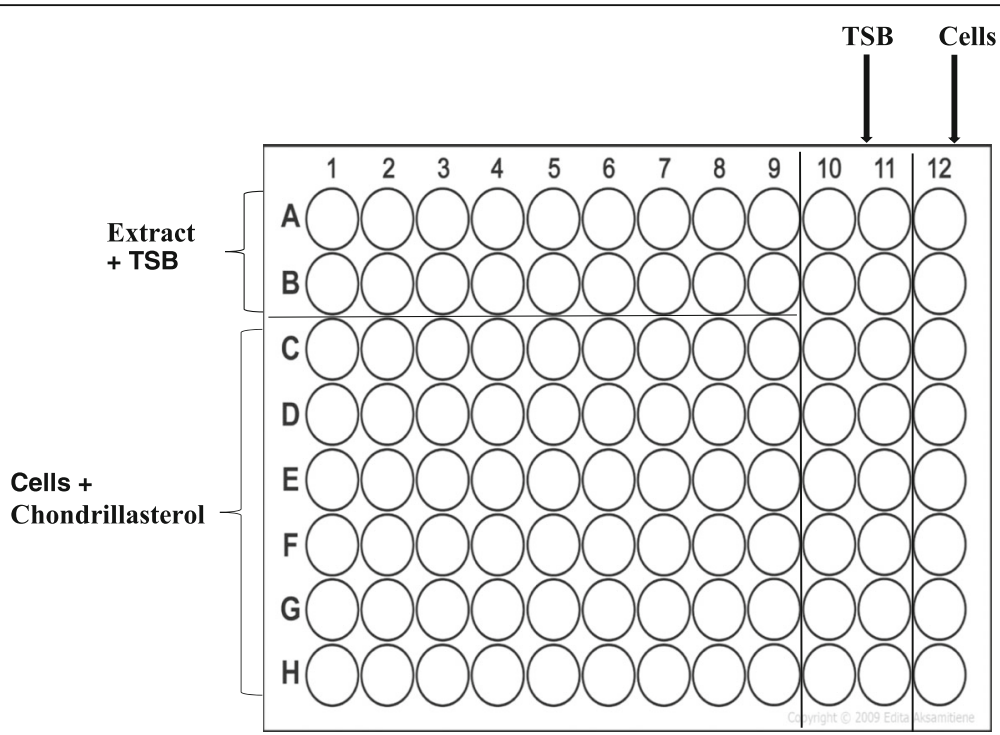

Fig. 1 Plate layout for testing effect of chondrillasterol on mature biofilm. A two-fold serial dilution was carried out for chondrillasterol starting from $200 \mathrm{\mu g} / \mathrm{mL}$. Increasing concentrations of chondrillasterol were added starting from column C1. Controls included: (i) the extract being incubated alone (rows 1 and 2), (ii) media alone (column 10 and 11) and (iii) viable bacterial cells incubated alone (column 12)

the plate, $200 \mu \mathrm{L}$ of bacterial cells only were dispensed and served as the positive control. Aliquots of media (TSB $+1 \%$ glucose) were dispensed into each of eight wells of column 12 of microtiter plate to serve as a negative control. The plate was incubated at $37^{\circ} \mathrm{C}$ for $72 \mathrm{~h}$ without shaking in LAB Doctor Mini Incubater (MID SCI, USA) to allow for development of a mature biofilm. After incubation medium was aspirated with a pipette and the plate washed twice with $0.9 \%$ sterile phosphate buffered saline to remove non adherent cells. Serial dilutions of chondrillasterol ranging from 100 to $0.8 \mu \mathrm{g} / \mathrm{mL}$ were prepared and added to the wells with the preformed biofilm. The plate was incubated for $24 \mathrm{~h}$ at $37^{\circ} \mathrm{C}$ without shaking. After incubation, the contents were decanted into a discard container and the plate was washed three times with sterile phosphate buffered saline to remove free-floating non-adherent cells. The plate was dried upside-down for $15 \mathrm{~min}$ on absorbent paper in the biosafety cabinet and placed in an oven (Mermmert, Schwabach, Germany) at $60^{\circ} \mathrm{C}$ for an hour to fix the formed biofilm. The amount of biofilm that remained on the plate after exposure of a preformed biofilm to different concentration of the compound was quantified by crystal violet (CV) staining as described in earlier. The controls used were similar to those used in the assay to determine effect of the compound on formation of biofilm by $P$. aeruginosa.

\section{Statistical analysis}

The data of the results obtained in this study were analysed using GraphPad Prism 5 for Windows (GraphPad Software Inc., San Diego, California, USA) version 5.03.
The one-way analysis of variance test (ANOVA) with Dunnett's Multiple Comparison Test was used to determine the level of significance where all treated samples were compared to the control. The values with $P<0.05$ were considered statistically significant.

\section{Results}

\section{Isolation of compounds}

Column chromatography of the acetone extract resulted in 450 fractions being collected. These fractions were combined into 20 pools in which most pools had a mixture of many compounds which were not pure. Only two pools labelled P19 and P7 had TLC profile showing the presence of three compounds while F10 and P16 had two and one compound respectively as shown in Fig. 2. The presence of a single spot from P16 implied that a pure compound had been isolated. However, no further analysis was done as the compound was in minute quantity. Further separation of compounds in the pool labelled F10 led to the isolation of two pure compounds which were labelled F10b1 and F10b2. Spectrometric analysis of the pure compound in F10b2 revealed that the compound was a wax. Outlined below is the data for the compound in F10b1: ${ }^{1} \mathrm{H}$ NMR $\left(\mathrm{CD}_{2} \mathrm{Cl}_{2}, 500 \mathrm{MHz}\right),(\mathrm{ppm}): 5.23(1 \mathrm{H}$, $\mathrm{dd}, \mathrm{J}=8.5 \mathrm{~Hz}, \mathrm{H}-22), 5.21(1 \mathrm{H}, \mathrm{m}, \mathrm{H}-7), 5.10(1 \mathrm{H}, \mathrm{dd}, \mathrm{J}=$ $8.5 \mathrm{~Hz}, \mathrm{H}-23), 3.58(1 \mathrm{H}, \mathrm{m}, \mathrm{H}-3), 1.07(3 \mathrm{H}, \mathrm{d}, \mathrm{J}=6.5 \mathrm{~Hz}$, $\mathrm{H}-21), 0.89(3 \mathrm{H}, \mathrm{d}, \mathrm{J}=6.5 \mathrm{~Hz}, \mathrm{H}-27), 0.85(3 \mathrm{H}, \mathrm{t}, \mathrm{J}=6.0$ $\mathrm{Hz}, \mathrm{H}-29), 0.84(3 \mathrm{H}, \mathrm{s}, \mathrm{H}-26), 0.83(3 \mathrm{H}, \mathrm{d}, \mathrm{J}=6.0 \mathrm{~Hz}, \mathrm{H}-$ 19), $0.59(3 \mathrm{H}, \mathrm{s}, \mathrm{H}-18){ }^{13} \mathrm{C}$ NMR $\left(\mathrm{CD}_{2} \mathrm{Cl}_{2}, 125 \mathrm{MHz}\right)$, (ppm):139.54 (C-8), 138.29 (C-22), 129.37 (C-23), 117.39 (C-7), 70.80 (C-3), 55.90 (C-14), 55.09 (C-17), 51.28 (C24), 49.45 (C-9), 43.22 (C-13), 40.85 (C-20), 40.28 (C-5), 


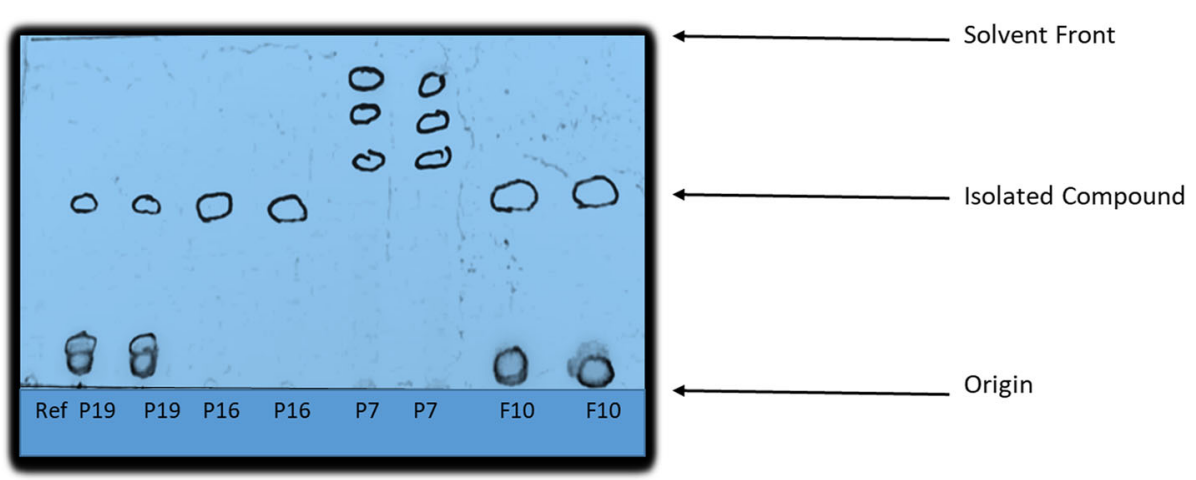

Fig. 2 TLC profile of compounds from column chromatography. Single spot represents a pure compound while more than one spot represents a mixture of compounds isolated from $\mathrm{V}$. adoensis

39.46 (C-12), $37.11(\mathrm{C}-1), 34.16(\mathrm{C}-16), 31.92(\mathrm{C}-25)$, 31.51 (C-2), 29.68 (C-6), 29.64 (C-16), 25.39 (C-28), 22.99 (C-11), 21.25 (C-15), 21.13 (C-21), 20.84 (C-26), 18.73 (C27), 12.78 (C-19), 12.02 (C-29), 11.78 (C-18). Spectrometric analysis of the compound showed that F10b1 was chondrillasterol and the structure is shown in Fig. 3 with NMR data provided as suplementary material (see Additional file 1: Figure S1). The proton and carbon-13 NMR spectra were comparable to published literature ([37]. Further antimicrobial assays were done using chondrillasterol.

\section{Antibacterial activity of chondrillasterol}

In-vitro tests were carried out to evaluate antibacterial activities of the isolated compound on P. aeruginosa, S. aureus and K. pneumoniae. Chondrillasterol was shown to possess antibacterial activity against all the tested strains (Fig. 4).

The most susceptible bacterium was $P$. aeruginosa whose growth was inhibited by $65 \%$ (Fig. $4 \mathrm{a}$ ). Chondrillasterol also inhibited the growth of $K$. pneumoniae and S. aureus by $38 \%$ (Fig. 4b) and 25\% (Fig. 4c) respectively.

\section{Effect of chondrillasterol on nucleic acid leakage}

Quantification of nucleic acids after exposure to chondrillasterol was performed to evaluate if the compound

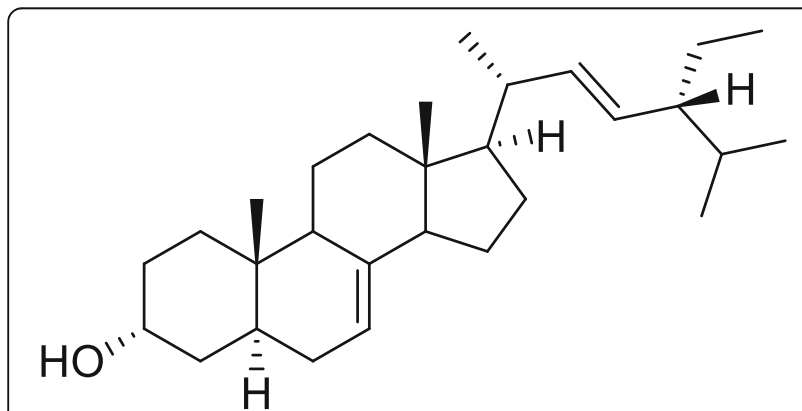

Fig. 3 Structure of Chondrillasterol. Data to elucidate the structure was obtained by NMR and MS studies had the ability to interfere with the integrity of $P$. aeruginosa membrane and cause leakage of nucleic acid from the bacteria. It was shown that 100 and $50 \mu \mathrm{g} / \mathrm{mL}$ caused nucleic acid leakage of 0.650 and $0.606 \mathrm{~F} / \mathrm{units}$ from $P$. aeruginosa respectively (Fig. 5). There was no statistically significant difference between nucleic acids leaked from cells exposed to chondrillasterol and nucleic acids leaked from untreated cells $(0.578 \mathrm{~F} /$ units). Sodium dodecyl sulphate (SDS) caused significant leakage of nucleic acids from P. aeruginosa and the fluorescence of PI from cells exposed SDS was 5.047 F/units.

\section{Effect of Chondrillasterol on formation of biofilm}

$P$. aeruginosa cells were allowed to form biofilms in microplate in the presence and absence of chondrillasterol. Biofilm mass that was formed after $72 \mathrm{~h}$ of incubation was stained with crystal violet and the results are shown in Fig. 6.

There was a significant difference in the biofilm formed by bacteria exposed to chondrillasterol from $6.3 \mu \mathrm{g} / \mathrm{mL}$ and the biofilm formed in bacteria not exposed to the compound (cells only). The results also show that at $100 \mu \mathrm{g} / \mathrm{mL}$ chondrillasterol completely inhibited the formation of biofilms in microplates by $P$. aeruginosa.

\section{Effect of chondrillasterol on disruption of biofilm}

Static biofilm quantification using the crystal violet method was performed to evaluate the effect of chondrillasterol on preformed $P$. aeruginosa biofilms in microplates. From the data shown in Fig. 7, the results show that all the tested concentrations of the isolated compound significantly disrupted preformed $P$. aeruginosa biofilms. The minimum concentration of chondrillasterol which disrupted $P$. aeruginosa biofilms was $1.6 \mu \mathrm{g} / \mathrm{mL}$ (Fig. 7).

\section{Discussion}

A number of bioactive plant secondary metabolite compounds have been isolated from crude extracts and their 


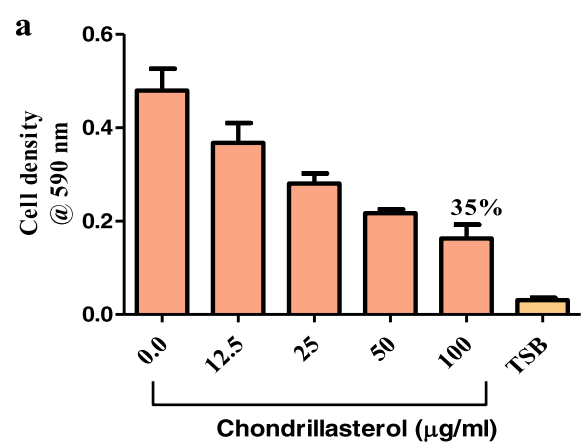

c

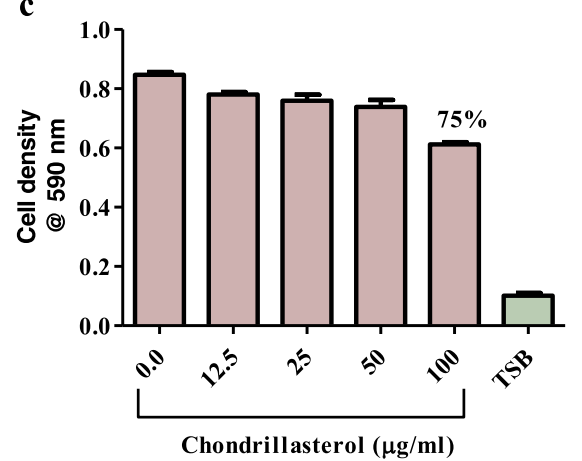

b

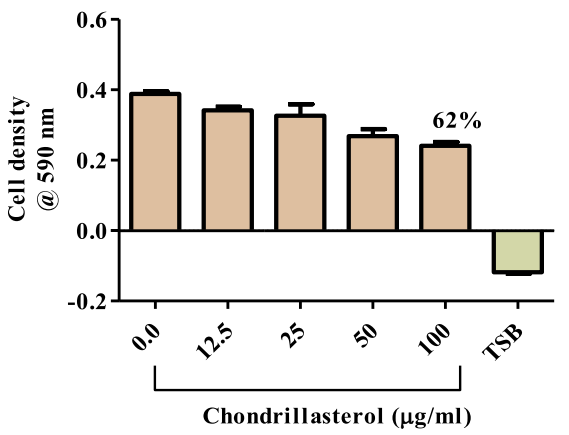

Fig. 4 The effect of chondrillasterol on growth of bacteria pathogens. The pathogens were susceptible to chondrillasterol and (a) is \% remaining viable cells for $P$. aeruginosa, and (b) is \% of remaining viable cells for $K$. pneumoniae while (c) is \% of remaining viable cells for $S$. aureus following exposure to chondrillasterol. Concentrations of $1.6 \times 10^{6} \mathrm{cfu} / \mathrm{mL}$ of bacteria were used. Values are expressed as mean cell density at $590 \mathrm{~nm}$ wavelength \pm the standard deviation $(n=4)$. TSB is tryptic soy broth

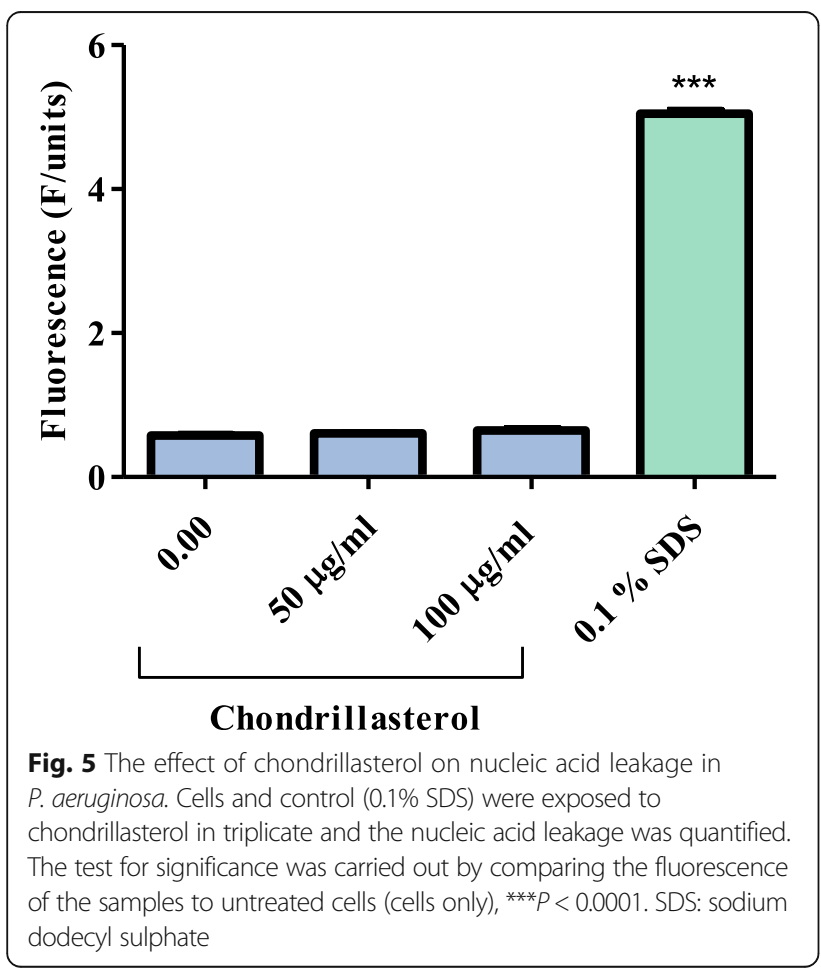

structures were elucidated [38]. In this study, phytochemical investigation on the acetone extract of the leaf parts of $V$. adoensis resulted in isolation and structure elucidation of one compound; chondrillasterol. There are studies which have been done and also resulted in isolation of pure compounds from $V$. adoensis [39]. However, to the best of our knowledge this is the first time that the compound chondrillasterol has been isolated from this plant. Chondrillasterol had, however, been previously identified from Agaratum fasigiatum which is from the same family (Asteraceae) with $V$. adoensis [40]. Chondrillasterol had also been isolated from other species including Gambeya boiviniana Pierre [37] and Lagenaria leucantha var.gourda [41]. Isolation and identification of bioactive compounds found in crude plant extracts as building blocks for new antibiotics provides unique opportunities for the development of new effective antibiotics. In this study the bioactivity of the isolated compound was evaluated against the bacterial species; S. aureus, $P$. aeruginosa and K. pneumoniae. Antimicrobial susceptibility was observed with the isolated compound which had an inhibitory effect on the growth of all the tested strains. These results are in agreement with similar studies which have been done and shown that compounds isolated from plants have antibacterial activity against microbial pathogens [41]. 

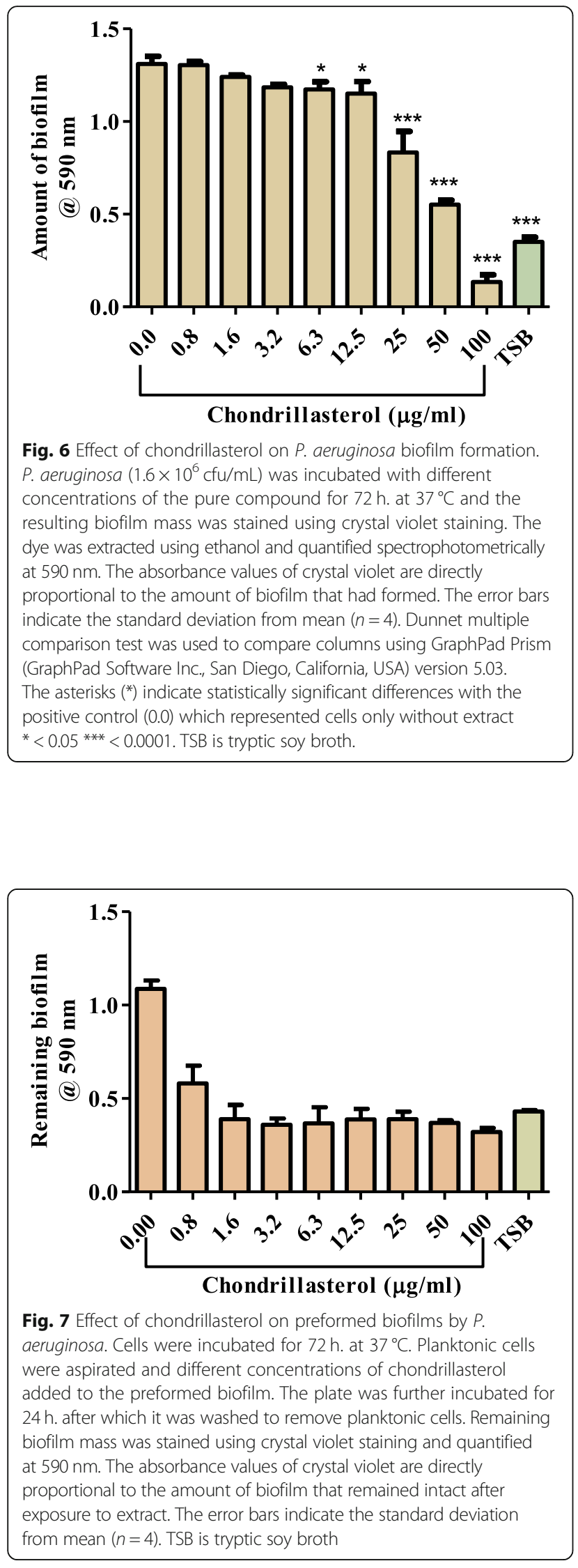

Chondrillasterol exhibited lower antibacterial activity than that reported for the crude extract [31]. This might mean that the extract had compounds that exerted their antibacterial effect in a synergistic manner. Though the three microorganisms were sensitive to chondrillasterol, the most sensitive organisms were the Gram-negative bacteria, $P$. aeruginosa followed by K. pneumoniae. There are reports in literature that Gram-negative bacteria are less susceptible to antimicrobial agents because of the presence of the outer membrane which acts as a permeability barrier $[42,43]$. The isolated compound is lipophilic which may result in it being able to penetrate the membrane barrier by dissolving in the lipid bilayer. Antibiotics which have been reported to be effective against the Gram-negative bacteria traverse the outer membrane by using the diffusion pathway through the lipid components of the outer membrane. They also traverse the membrane through porins or selective channels formed by specific beta-barrel proteins [44]. It is possible that chondrillasterol may be penetrating the membrane barrier using similar mechanism of action against $P$. aeruginosa and $K$. pneumoniae. However, the mechanism of action to effectively penetrate the membrane barrier may also be different from that being used by the current antibiotics. Previous studies have shown that natural products of higher plants may serve as sources of antimicrobial agents with possibly novel mechanisms of action [45, 46]. Antibacterial agents have also been shown to use different modes of action against bacterial pathogens, including altering membrane, protein leakage, and nucleic acid leakage [47]. To investigate the antibacterial mechanism of action of the isolated compound on the most susceptible bacteria, the ability of the isolated compound to disrupt $P$. aeruginosa membrane was determined. The results showed that chondrillasterol did not cause any leakage of nucleic acids from $P$. aeruginosa and may mean that the compound may be using a different mechanism of action and not killing the bacteria by causing leakage of nucleic acids. The antibacterial activity of the pure compound was, however, found to be lower than that of the standard antibiotic ciprofloxacin. The use of natural compounds with antibacterial activity is now increasingly being encouraged since natural products are perceived to be safe and mitigate many of the side effects that are often associated with conventional antimicrobials $[6,48]$.

Compounds isolated from plants have been shown to exhibit antibiofilm activity [49]. Clinically, biofilm inhibitors can be used directly to reduce virulence factors from infectious bacteria [50] or to treat infectious biofilm along with conventional antibiotics [51]. In this study, the antibiofilm potential of the isolated compound was evaluated against $P$. aeruginosa. $P$. aeruginosa is a ubiquitous bacterium in nature and this opportunistic pathogen can colonise various surfaces by forming a 
biofilm in which bacterial cells stick together and are embedded within a self-produced extracellular polysaccharide matrix $[52,53]$. Cells which are in a biofilm are reported to be more resistant to antibiotics and biocides than planktonic cells, which often cause difficulties in eradicating them from individuals infected with the bacterium [54]. Chondrillasterol inhibited formation of biofilm by P. aeruginosa. The inhibition of biofilm formation by chondrillasterol was found to be concentration-dependent. An increase in concentration of chondrillasterol caused increased suppression of bacterial growth and this suggests that suppression of biofilm formation by the compound may be resulting from the inhibition of bacterial growth. The ability of a natural product to completely inhibit biofilm formation suggests that it would be a good candidate for use in controlling biofilm growth. Such compounds with anti-biofilm activities may be used directly to reduce virulence factors from infectious bacteria [50] or to treat biofilm along with conventional antibiotics [51]. Development of antibiofilm agents is very important as attempting to simply kill bacteria using antimicrobial treatment only is often insufficient when dealing with infections from biofilm-forming microbes such as $P$. aeruginosa. Antibiofilm agents may influence biofilm formation by damaging microbial membrane structures, inhibiting peptidoglycan synthesis, and/or modulating quorum sensing [55]. The mechanism of inhibition of biofilm formation of the isolated compound against $P$. aeruginosa still remains to be elucidated. Phytochemicals such as steroids have been shown to associate with bacterial proteins and inhibit microbial adhesion, enzymes cell envelop and transport proteins [56, 57]. It is possible that chondrillasterol inhibited biofilm formation through some of these mechanisms. One of the most significant features of bacterial biofilms is their resistance to antimicrobial agents [58]. Investigations into the mechanism of resistance revealed that, nutrient limitation, low bacterial growth rate and reduced drug penetration into the biofilms are all contributing factors [59].

Biofilm related infections can be efficiently eradicated by using antibiofilm agents that weaken or destroy the mature biofilm rendering cells to be susceptible to antibiotics [60]. The weakening or destruction of the mature biomass can be followed by washout or subsequent biocidal inactivation of the detached biomass $[61,62]$. Chondrillasterol concentrations significantly disrupted mature biofilms of $P$. aeruginosa. The result suggests that the compound is an effective biofilm disruptor which can be used to control $P$. aeruginosa infections. A biofilm disrupting agent may increase penetration of antibiotics in the biofilm [63]. This is very important in reducing bacteria drug tolerance as it has been proposed that antibiotics that penetrate more slowly may give time for an adaptive phenotypic response that could potentially increase tolerance $[63,64]$. Bacteria in biofilms have been shown to behave differently which make it difficult for the immune system to recognise and fight them $[65,66]$. However, once a biofilm disruptor have been administered, cure can be obtained even without concurrent administration with antibiotics. This is because once the biofilm has been disrupted and cells are now in planktonic form then the cells will be exposed to vast immune intervention mechanisms produced by host against the pathogens [67]. Chondrillasterol may be used as an agent for disrupting biofilms and this may significantly diminish morbidity associated with biofilm related nosocomial infection [68]. Effective treatments for the disruption of established biofilms could save many lives and decrease healthcare costs related to the treatment and potential replacement of infected implanted prosthetic devices [69].

\section{Conclusion}

Chondrillasterol was isolated from $V$. adoensis leaves. The compound has antibacterial activity against $P$. aeruginosa S. aureus and $K$. pneumoniae. Chondrillasterol inhibited biofilm formation in $P$. aeruginosa as well as disrupted already formed mature biofilms. Therefore, this compound may be useful in the development of antibacterial agents to treat biofilm-related infections.

\section{Recommendations}

Further work is required to evaluate the mechanism of action of the compound as an antibiofilm agent as well as evaluation of its antibacterial potential and mechanism of action on a number of pathogens. The toxicity profile of the compound also needs to be evaluated. Further isolation and purification of fractions from other parts of this plant are recommended which could yield some novel bioactive compounds.

\section{Additional file}

Additional file 1: Figure S1. NMR spectra of the various $2 \mathrm{D}$ experiments including $\mathrm{H}, \mathrm{H}-\mathrm{COSY}, \mathrm{HSQC}, \mathrm{HMBC}$ and NOESY used for structure elucidation of chondrillasterol. (PDF 1870 kb)

\section{Abbreviations}

ATCC: American Type Culture Collection; MTT: 3-(4,5-dimethylthiazol-2-yl)-2, 5-diphenyltetrazolium bromide; TLC: Thin layer chromatography

\section{Acknowledgements}

The authors acknowledge the assistance of Mr. Christopher Chapano, a taxonomist with the National Herbarium and Botanical Gardens, Harare, Zimbabwe in the authentication of the plant sample names. Professor Matthias Heydenreich and his Research Group of Analytical Chemistry is acknowledged for the spectroscopic analysis of the isolated compound. The authors also acknowledge Dr. Chi Godloves Fru for interpreting the NMR data.

Authors' contributions

WM conducted all the experimental studies and data analysis. DT assisted with the column chromatography work. SM conceptualised, designed and directed the study. All authors read and approved the final manuscript. 


\section{Authors' information}

Professor Stanley Mukanganyama is a Professor of Biochemistry at the University of Zimbabwe. He holds a PhD in Biochemistry and specialised in drug metabolism, particularly the contribution of Phase II enzyme systems in xenobiochemistry. He is a member of the Biochemistry and Molecular Biology Society of Zimbabwe (BMBSZ), is the Head of the Department of Biochemistry and the In-country president of the Natural Products Research of Eastern and Central Africa (NAPRECA-Zimbabwe. Ms. Winnie Mozirandi (B.Tech. Hons. Biotechnology, M.Phil. Medicine) is a PhD student in the Department of Biochemistry. Prof. Dexter Tagwireyi is an Associate Professor and the Director at the School of Pharmacy, University of Zimbabwe. He does research in Applied Toxicology, Natural Products Pharmacology and Toxicology. He has experience and expertise in neurobehavioral pharmacology, experimental Toxicology, toxicology, toxicoepidemiology, LCMS spectrometry, FTIR, UVNis spectroscopy, low field bench top NMR and formulation of complementary medicines.

\section{Funding}

Support from the International Science Programmes (ISP) through the International Program in the Chemical Sciences (ISP IPICS: ZIM01, Uppsala University, Uppsala, Sweden) and the International Foundation in Sciences (IFS F/3413-03F, Stockholm, Sweden) is acknowledged. F/3413-03F supported research under the title: "Screening natural plant products from selected plants from Zimbabwe as a source of anti-infective compounds for phytomedicines development". ISP IPICS: ZIM01 supported the research under the title "Biomolecular Interactions Analyses". Support from the Alliance for Global Health and Science (University of California, Berkeley).

\section{Availability of data and materials}

The datasets used and/or analysed during the current study available from the corresponding author on reasonable request.

\section{Ethics approval}

The study was conducted according to the protocol approved by the Faculty of Science Higher Degrees committee (FSHDC), paper HD/166 of 2016, University of Zimbabwe.

\section{Consent for publication}

Not applicable.

\section{Competing interests}

The authors declare that they have no competing interests.

\section{Author details}

'Department of Biochemistry, University of Zimbabwe, P.O. Box MP 167, Mt. Pleasant, Harare, Zimbabwe. ${ }^{2}$ School of Pharmacy, College of Health Sciences, University of Zimbabwe, P.O. Box A178, Avondale, Harare, Zimbabwe.

\section{Received: 14 June 2019 Accepted: 27 August 2019}

Published online: 06 September 2019

\section{References}

1. AL-Bari MA, Rahman MA, Mossadik M, Sayeed M. Characterisation and antimicrobial activities of a phenolic acid derivative produced by Streptomyces bangladeshiens a novel species collected in Bangladesh. Res Jounal Med Med plants. 2006;1:77-8.

2. Ara N, Nur MH, Amran MS, Wahid Ml, Ahmed M. In vitro antimicrobial and cytotoxic activities of leaves and flowers extracts from Lippia alba. Pakistan J Biol Sci. 2009;12:87-90.

3. Koczan MJ, Lenneman BR, McCathy MJ, Sundin GW. Cell surface attached structures contribute to biofilm formation and xylem colonisation by Erwinia amylovera. Appl Environ Microbiol. 2011;77:7031-9.

4. Vandevelde NM, Tulkens PM, Van Bambeke F. Antibiotic activity against naive and induced streptoccocus pneumonia biofilms in an in vitropharmacodynamic model. Antimicrob agents Chemother. 2014;58: 1348-58.

5. Suci PA, Mittelman MW, Yu FP, Geesey G. Investigation of ciprofloxacin penetration into Pseudomonas aeruginosa biofilms. Antimicrob Agents Chemother. 1994;38:2125-21331.
6. Guarrera PM. Traditional phytotherapy in Central Italy (Marche, Abruzzo, and Latium). Fitoterapia. 2005;76:1-25.

7. Gurib-Fakim A. Medicinal plants: traditions of yesterday and drugs of tomorrow. Mol Asp Med. 2006;27:1-93.

8. Silva MC, Carvalho J. Plantas medicinais: Fitoterapicos. Anti- inflamatorios. Aspectos quimicos, farmacologicose aplicacoes terapeuticas. Asp Quim Farmacol Apl Ter. 2004;SP.

9. Kisangau DP, Hosea KM, Joseph CC, Lyaruu HVM. In vitro antimicrobial assay of plants used in traditional medicine in Bukoba rural district, Tanzania. African J Tradit Complement Altern Med. 2007;4:510-23.

10. Toyang JN, Verpoorte R. A review of the medicinal potentials of plants of the genus Vernonia (Asteraceae). J Ethnopharmacol. 2013;146:681-723.

11. Kokwaro JO. Medicinal plants of East Africa. Third Edition. Nairobi Univ Press. 2009. p. 478.

12. Stangeland T, Alele $P$, Katuura E, Lye KA. Plants used to treat malaria in Nyakayojo sub-county, western Uganda. J Ethnopharmacol. 2011;137:154-66.

13. Hyde MA, Wursten BT, Ballings P, Coates PM. Flora of Zimbabwe: species information: Vernonia adoensis; 2012.

14. Muhindi SW, Ngule CM, Ramesh F. Phytochemical and antibacterial potential of Vernonia Adoensis stem bark to curb cariogenic microorganisms. Am J Phytomedicine Clin Ther. 2016;4:19-27.

15. Mautsa R, Mukanganyama S. Vernonia adoensis leaf extracts cause cellular membrane disruption and nucleic acid leakage in Mycobacterium smegmatis. J Biol Act Prod from Nat. 2017;7:140-56.

16. Chitemerere TA, Mukanganyama S. In vitro antibacterial activity of selected medicinal plants from Zimbabwe. African J Plant Sci Biotechnol. 2011;5:1-7.

17. Stangeland T, Wangensteen H, Katuura E, Lye KA, Paulsen BS. Antioxidant and ant-plasmodial activity of extracts from three Ugandan medicinal plants. J Med plants Res. 2010;4:1916-23.

18. Luo X, Jiang Y, Fronczek FR, Lin C, Izevbigie EB, Lee KS. Isolation and structure determination of a sesquiterpene lactone (vernodalinol) from Vernonia amygdalina extracts. Pharm Biol. 2011;49:464-70.

19. Abay SM, Lucantoni L, Dahiya GG, Dori EG, Dembo G, Lupidi. Plasmodium transmission blocking activities of Vernonia amygdalina extracts and isolated compounds. Malar J. 2015;14:288.

20. Erasto P, Grierson DS, Afolayan AJ. Bioactive sesquiterpene lactones from the leaves of Vernonia amygdalina. J Ethnopharmacol. 2006;106:117-20.

21. Thangiah AS, Obey J, Mutuku NC. Phytochemical analysis of Vernonia adoensis leaves and roots used as a traditional medicinal plant in Kenya. Int J Pharm Biol Sci. 2013:3:46-52.

22. Rice LB. Progress and challenges in implementing the research on ESKAPE pathogens. Infect Control Hosp Epidemiol. 2010;31:S7-S10.

23. Tenover FC. Mechanism of antimicrobial resistance in bacteria. Am J Med. 2006;119:S3-10.

24. Simona Bratu M, David Landman M, Robin Haag R, Rose Recco M, Antonella Eramo R, Maqsood Alam M, et al. Rapid Spread of Carbapenem-Resistant Klebsiella pneumoniae in New York City. Archives of Internal Medicine. 2014;165:1430-5.

25. Chambers HF. The changing epidemiology of Stappylococcus aureus. Emerg Infect Dis. 2001;7:178-82.

26. Abushanab B, Adwan G, Abu-safiya D, Adwan K. Antibacterial activities of some plant extracts utilised in popular medicine in Palestine. Turkish J Biol. 2004:28:99-102

27. Lyczak JB, Cannon CL, Pier GB. Lung infections associated with cystic fibrosis. Clin Microbiol Rev. 2002;15:194-222.

28. Cos P, Sindambiwe L, Vlietink A, Berghe D. Bioassays for antimicrobial and antifungal activities. In: Edited by Mahabir P, Gupta S, Swami H KV, editor. Trieste, International Centre for Science and High Technology; 2006. p. 19-28.

29. Cowan MM. Plant products as antimicrobial agents. Clin Microbiol. 1999;12: 564-82.

30. Amor ILB, Boubaker MB, Sgaier I, Skandrani, Bhouri W. Phytochemistry and biological activities of Phlomis species. J Ethnopharmacol. 2009;125:183-202.

31. Mozirandi W, Mukanganyama S. Antibacterial activity and mode of action of Vernonia adoensis (Asteraceae) extracts against Staphylococcus aureus and Pseudomonas aeruginosa. J Biol Act Prod from Nat. 2017;7:341-57.

32. Okeke MI, Iroegbu CU, Eze EN, Okoli AS, Esimone CO. Evaluation of extracts of the root of Landolphia owerrience for antibacterial activity. J Ethnopharmacol. 2001;78:119-27.

33. EUCAST (European Committee for Antimicrobial Susceptibility Testing). Determination of minimum inhibitory concentrations (MICs) of antibacterial agents by broth dilution. Clin Microbiol Infect Dis. 2003;9:1-7. 
34. Mosmann T. Rapid colorimetric assay for cellular growth and cytotoxicity assays. J Immunol Methods. 1983;65:55-63.

35. El-Nakeeb MA, Abou-Shleib HM, Khalil AM, Omar HG, El-Halfawy O. Membrane permeability alteration of some bacterial clinical isolates by selected antihistaminics. Brazilian J Microbiol. 2011;42:992-1000.

36. Stepanovic S, Vukovic D, Hola V, Di Bonaventura G, Djukić S, Irkovic I, et al. Quantification of biofilm in microtiter plates: overview of testing conditions and practical recommendations for assessment of biofilm production by staphylococci. APMIS. 2007;115:891-9.

37. Rasoanaivo LH, Wadouachi A, Andriamampianina TT, Andriamalala GS, Jeannot EB, Raharisololalao A, et al. Triterpenes and steroids from the stem bark of Gambeya boiviniana Pierre. J Pharmacogn Phytochem. 2014;3:68-72.

38. Bajpai V, Kang S. Isolation and characterization of biologically active secondary metabolites from Metasequoia glyptostroboides Miki ex Hu. J Food Saf. 2011;31:276-83.

39. Bohlmann F, Scheidges C, Misra LN, Jakupovic J. Further glaucolides from south african Vernonia species. Phytochemistry. 1984;23:1795-8.

40. Gonçalves LDA, Hugo R, Oliveira De PM, Lopes NP, Turatti ICC, Fernando C, et al. Contribution for the phytochemical studies of Ageratum fastigiatum. Brazilian J Pharmacogn 2011;21:936-942.

41. Itoh T, Kikuchi Y, Tamura T, Matsomoto T. Co-occurrence of chondrillasterol and spinasterol in two Cocurbitaceae seeds as shown by 13C NMR. Phytochemistry. 1981;20:761-4.

42. Awolola GV, Chenia H, Baijnath H. A KN. Anti-adhesion potential of nonpolar compounds and extracts from Ficus natalensis. Brazilian J Jharmacology. 2017;27:599-602.

43. Udochukwu U, Omeje FI, Uloma IS, Oseiwe FD. Phytochemical analysis of Vernonia amygdalina and Ocimum gratissimum exrtracts and their antibacterial activity on some drug resistant bacteria. Am J Res Commun. 2015;3:225-35.

44. Titilawo O, Ogundare A, Olaitan J. Mechanism of action of the leaf and bark extract of Vernonia ternoreana. Niger J Microbiol. 2011;25:2261-8.

45. Miller SI. Antibiotic resistance and regulation of the gram-negative bacterial outer membrane barrier by host innate mmune molecules. Am Soc Microbiol. 2016;7:e01541-16.

46. Ahmad I, Aqil F. In vitro efficacy of bioactive extracts of 15 medicinal plants against ES?L- producing multidrug-resistantenteric bacteria. Microbiol Res. 2007;162:264-75.

47. Barbour EK, Al Sharif M, Sagherian VK. Screening of selected indigenous plants of Lebanon for antimicrobial activity. J Ethnopharmacol. 2004;93:1-7.

48. Ali W, Raza A, Ahmad W, Ali MA, Tawseen H, Aslam M, et al. Modes of action of some recently and previously discovered and used antimicrobial agents/ drugs and molecules: An Overview. J Pharmacogenomics

Pharmacoproteomics. 2017;8:doi: https://doi.org/10.4172/2153-0645.1000171.

49. Iwu MW, Duncan AR, Okunji CO. New antimicrobials of plant origin. In: Janick J, editor. Perspectives on new crops and new uses. Alexandria: AHSH Press; 1999. p. 457-62.

50. Koo H, Jeon JG. Naturally occurring molecules as alternative therapeutic agents against cariogenic biofilms. Adv Dent Res. 2009;21:63-8.

51. Davies D. Understanding biofilm resistance to antibacterial agents. Natl Rev drug Discov. 2003;2:114-22.

52. Clatworthy AE, Pierson E, Hung DT. Targeting virulence: a new paradigm for antimicrobial therapy. Nat Chem Biol. 2007;3:541-8.

53. Smith A. Biofilms and antibiotic therapy: is there a role for combating bacterial resistance by the use of novel drug delivery systems? Advers Drug Deliv Rev. 2005;57:1539-50.

54. Drenkard E, Ausubel F. Pseudomonas biofilm formation and antibiotic resistance are linked to phenotypic variation. Nature. 2002;416:740-3.

55. Chmielewsky RAN, Frank JF. Biofilm formation and control in food processing facilities. Compr Rev Food Sci Food Saf. 2003;2:22-32.

56. Sillankorv S, Oliveira R, Vieira MJ, Sutherland I, Azeredo J. Bacteriophage $\Phi$ S1 infection of Pseudomonas fluorescens planktonic cells versus biofi Ims. J Biofouling. 2004:20:133-8.

57. Upadhyay A, Upadhyaya I, Kollanoor-Johny A, Venkitanarayanan K. Combating pathogenic microorganisms using plant-derived antimicrobials: a Mini review of the mechanistic basis. Biomed Res Int. 2014;2:761-41.

58. Samy RP, Gopalakrishnakone P. Therapeutic potential of plants as antimicrobials for drug discovery. Evidence-Based Compl Alt Med. 2008;7:283.

59. Schlag S, Nerz C, Birkenstock T, Altenberend F, Got ZF. Inhibition of staphylococcal biofilm formation by nitrite. J Bacteriol. 2007;189:7911-9.

60. Brown MRW, Gilbert P. Sensitivity of biofilms to antimicrobial agents. J Appl Bacteriol - Symp Supplemen. 1993;74:87S-97S.
61. Steven LP, Bowler GP. Biofilms and their potential role in wound healing; 2004.

62. Davies $D$, Marques C. A fatty acid messenger is responsible for inducing dispersion in microbial biofilms. J Bacteriol. 2009;191:1393-403.

63. Rogers S, Huigens lii RW, Melander C. A 2-aminobenzimidazole that inhibits and disperses gram-positive biofilms through a zinc-dependent mechanism. J Am Chem Soc. 2009;131:9868-9.

64. Walters M, Roe F, Bugnicourt A. Contributions of antibiotic penetration, oxygen limitation, and low metabolic activity to tolerance of Pseudomonas aeruginosa biofilms to ciprofloxacin and tobramycin 2003;47. Antimicrob Agents Chemother. 2003;47:317-23.

65. Tseng B, Zhang W, Harrison JJ. The extracellular matrix protects Pseudomonas aeruginosa biofilms by limiting the penetration of tobramycin. Enviromental Microbiol. 2013;15:2865-78.

66. Costerton JW. Bacterial Biofilms : A Common Cause of Persistent Infections. Science (80- ). 1999;284

67. Hall-Stoodley L, Stoodley P. Evolving concepts in biofilm infections. Cell Microbiol. 2009;11:1034-43.

68. Ojha A, Anand M, Jacobs WR, Bhatt A, Kreme L, Hatfull G, et al. A dedicated chaperone involved in mycolic acid biosynthesis during mycobacterial growth in biofilms. Cell. 2015;123:861-73.

69. Hawser SP, Douglas $\sqcup$. Biofilm formation by Candida species on the surface of catheter materials in vitro. Infect Immun. 1994;62:915-21.

\section{Publisher's Note}

Springer Nature remains neutral with regard to jurisdictional claims in published maps and institutional affiliations.
Ready to submit your research? Choose BMC and benefit from:

- fast, convenient online submission

- thorough peer review by experienced researchers in your field

- rapid publication on acceptance

- support for research data, including large and complex data types

- gold Open Access which fosters wider collaboration and increased citations

- maximum visibility for your research: over $100 \mathrm{M}$ website views per year

At $\mathrm{BMC}$, research is always in progress.

Learn more biomedcentral.com/submissions 